\title{
Metal Extraction Process for High Grade Stibnite of Kharan (Balochistan Pakistan)
}

\author{
Irfan Hafeez, Saqib Nasir*, Samreen Zahra, Muhammad Aamir, Zahid Mahmood, Adnan Akram \\ Mineral Processing Research Centre, Pakistan Council of Scientific \& Industrial Research Laboratories Complex, \\ Lahore, Pakistan \\ Email: *saqibnasir@hotmail.com
}

How to cite this paper: Hafeez, I., Nasir, S., Zahra, S., Aamir, M., Mahmood, Z. and Akram, A. (2017) Metal Extraction Process for High Grade Stibnite of Kharan (Balochistan Pakistan). Journal of Minerals and Materials Characterization and Engineering, 5, 39-48.

http://dx.doi.org/10.4236/jmmce.2017.51004

Received: January 14, 2016

Accepted: January 9, 2017

Published: January 12, 2017

Copyright $\odot 2017$ by authors and Scientific Research Publishing Inc. This work is licensed under the Creative Commons Attribution International License (CC BY 4.0).

http://creativecommons.org/licenses/by/4.0/

\begin{abstract}
A rapid and simple process has been developed for the recovery of antimony metal from stibnite ore of Kharan area (Balochistan) of Pakistan. The ore was characterized by X-ray diffraction (XRD) technique and found to contain $66 \%$ stibnite i.e. antimony sulfide $\left(\mathrm{Sb}_{2} \mathrm{~S}_{3}\right)$. The process parameters for the extraction of antimony were optimized on laboratory scale by varying reaction temperature from $900^{\circ} \mathrm{C}-1000^{\circ} \mathrm{C}$, reaction time from $20-80$ minutes and flux concentration was varied from 5 - 25 weight percent of the reaction mixture. The metal thus recovered with optimum conditions was evaluated by X-ray fluorescence (XRF) technique and was found to be more than $94 \%$ pure. The recovery yield calculated on the basis of stibnite present in the ore was $98.52 \%$.
\end{abstract}

\section{Keywords}

Antimony, Stibnite, Extraction, Recovery Yield

\section{Introduction}

Stibnite, also called as antimonite, is a major source of antimony which is in fact its sulphide mineral $\left(\mathrm{Sb}_{2} \mathrm{~S}_{3}\right)$. It occurs enormously as veins mainly associated with quartz and other antimony minerals like antimony oxide, formed by the decomposition of stibnite. The abundant deposits of stibnite are found in Kharan, Qilla Abdullah, Kalat, Pishin, Kurram valley, Karangli hill, Krinj and Chitral areas of Pakistan [1]. In addition to these reserves, the deposits of stibnite are being discovered in Kharan [2], are economically feasible and should explore for country demand. These significant mineral deposits can be utilized effectively for the extraction of antimony metal as it contains $60 \%-66 \%$ stibnite mineral.

The extraction of metal from an ore mainly depends on its grade; low grade ores required up-gradation prior to extraction for the removal of associated 
gangue minerals which are often pyrite, sphalerite, calcite, barite and other clay mineral [1]. Such ores are usually up-graded by froth-flotation process [3] while high grade ores can be utilized directly for metal recovery due to substantial decrease in gangue content.

Antimony is usually extracted from its ores by either hydro-metallurgical or pyro-metallurgical processes. In addition to these, a variety of solvents have also been used in the past, for the extraction of antimony from aqueous solutions [4] [5]. Hydrometallurgical processes usually involve acid or alkaline leaching of ores. The acid leaching is often carried out by mineral acids i.e. hydrochloric acid, nitric acid and sulphuric acid. Since stibnite ore reacts slowly and incompletely with mineral acids alone, they have been used in combination with other reagents e.g. tartaric acid [6]. The reductive leaching using iron powder in mineral acid has also been reported for the efficient recovery of antimony from stibnite [7]. The other hydrometallurgical method commonly investigated by the researchers i.e. alkaline leaching, has been performed using solutions of either sodium hydroxide or sodium hydroxide along with sodium sulfide and $70 \%$ to $90 \%$ recovery of antimony has been achieved [8] [9] [10]. Veglio and co-worker have optimized parameters for alkaline leaching with sodium hydroxide and sodium sulfide using pure antimony sulfide instead of antimony ore and have obtained $98 \%-100 \%$ extraction yield of antimony during study [11]; however its yield decreases subsequently if the same procedure may be followed for the original ore. All these hydrometallurgical processes involve use of finer fractions of up-graded ores and leaching pre-treatment followed by separation of metal from the leach solution which is usually carried out by electro winning technology [12]. Moreover, these methods require several hours for their completion and involvement of numerous steps makes them relatively expensive and tedious. Furthermore acid leaching is accompanied by the evolution of hydrogen sulfide gas which is toxic and causes environmental hazards [7].

Pyro-metallurgical technique has also been used successfully by the previous researchers and found to be extremely beneficial for the recovery of antimony from its ores since reactants undergo spontaneous chemical changes due to application of high temperature and metal is readily separated from the molten mixture [13] [14]. In contrast to hydro-metallurgy, pyro-metallurgical routes are extensively used on commercial scale as it is economically viable although required high temperatures i.e. $1150^{\circ} \mathrm{C}$ to $1350^{\circ} \mathrm{C}$ and as a consequence produce toxic antimony vapours and sulphur dioxide gas. However, the sulphur dioxide gas produced can be converted to sulphuric acid by the well-known contact process which can subsequently reduce the environmental hazards of this technology. Analogous to hydrometallurgical procedures most of the previously developed pyro-metallurgical methods are multi-step processes which often begin with the smelting of concentrates [14] [15].

In view of the fact that antimony and its compounds are widely used in flame-retardants textile finishing compounds, lead alloys, semiconductors, ceramic enamels and pigments etc. [16], the present studies was undertaken to de- 
velop a one-step pathway for the recovery of antimony metal directly from stibnite high grade ore of Distt. Kharan (Balochistan) and can be employed for economic recovery of antimony metal without up-gradation. This can be achieved with iron reduction method [16] and the process parameters were optimized on laboratory scale to obtained maximum recovery of antimony metal.

\section{Experimental Methodology}

\subsection{Ore Samples}

Stibnite ore of Kharan area of Pakistan was employed for the extraction of metal which contains $66 \%$ antimony sulfide content. Iron scrape was used as a source of iron whereas analytical grade sodium chloride was used as a flux.

\subsection{Characterization of Stibnite Ore of Kharan}

Stibnite ore of Kharan was characterized by Xpert High Score Plus Diffractometer using monochromatised $\mathrm{CuK}_{\alpha}$ radiation having wavelength of $1.5404 \AA$.

\subsection{Extraction Procedure}

Stibnite ore of -30 mesh size was mixed with iron scrape in stoichiometric ratio according to the following equation [16]:

$$
\mathrm{Sb}_{2} \mathrm{~S}_{3}+3 \mathrm{Fe} \rightarrow 2 \mathrm{Sb}+3 \mathrm{FeS}
$$

The flux was then added and the mixture was heated at ambient temperature in graphite crucible on a gas fired furnace for constant time. The melting product contains molten antimony metal and slag; the slag obtained was a mixture of flux and iron sulfide formed as a by-product. The molten material was then poured into a mould and the metal was separated from iron sulfide.

The process parameters were optimized and the effect of temperature was studied in a range of $900^{\circ} \mathrm{C}$ to $1000^{\circ} \mathrm{C}$ and time was varied from 20 to $80 \mathrm{mi}-$ nutes whereas effect of flux i.e. sodium chloride was studied by varying its concentration from $5 \%$ to $25 \%$ by weight of reaction mixture.

\subsection{Characterization of Antimony Metal}

The final product obtained i.e. antimony metal was characterized by X-ray fluorescence technique (XRF) using Spectro Midex MID 01.

\section{Results and Discussion}

Stibnite ore of Kharan is a high grade ore and it contains $66 \%$ antimony sulfide as confirmed by X-ray diffraction (XRD) analysis. Therefore, up-gradation through froth-flotation is not required and instead of using concentrate the ore is employed directly for extraction of antimony metal as its recovery is better by iron precipitation since stibnite is a sulfide ore. The process is based on a displacement reaction in which iron displaces antimony in the sulfide mineral, as a result of which antimony sulfide is converted to antimony metal and iron sulfide is formed as a by-product which can be utilized for production of hydrogen sul- 
fide gas in Kipp's apparatus. In present study, the ore after crushing was ground to pass 30 mesh sieve and subjected to reduction using iron scrape in the presence of flux and the process parameters were optimized on laboratory scale by varying flux concentration at variable temperature and reaction time.

\subsection{X-Ray Diffraction Analysis}

Mineralogical composition of the stibnite ore was confirmed by X-ray diffraction analysis and diffraction pattern is illustrated in Figure 1. All the peaks were matched by the search-match program using Xpert High Score Plus Software which reveals that the ore predominantly consists of stibnite $\left(\mathrm{Sb}_{2} \mathrm{~S}_{3}\right)$ i.e. $66 \%$, whereas $6 \%$ senarmontite $\left(\mathrm{Sb}_{2} \mathrm{O}_{3}\right)$ was also detected as shown in Table 1 . These results suggest that it is a mixed ore but contains oxide mineral in a minor quantity as compared to sulfide. The host mineral was entirely composed of quartz $\left(\mathrm{SiO}_{2}\right)$ which was found to be $28 \%$. The remaining associated gangue minerals i.e. pyrite, sphalarite, calcite, barite and clay minerals might be present in traces, so these were not detected due to limitation of X-ray diffraction technique.

\subsection{Process Parameters Optimization}

\subsubsection{Effect of Reaction Temperature}

The temperature was varied from $900^{\circ} \mathrm{C}$ to $1000^{\circ} \mathrm{C}$ and its effect on the recovery of antimony metal was studied. The process was carried out at five different temperatures ranging from $900^{\circ} \mathrm{C}$ to $1000^{\circ} \mathrm{C}$ keeping time and flux concentration constant and results as shown in Table 3 . Sodium chloride $(\mathrm{NaCl})$ was used as flux in all the five experiments which was taken as $15 \%$ of the weight of the reaction mixture and the reaction was continued for 40 minutes. The results of experiments show a gradual increase in the recovery of antimony as the temperature changes from $900^{\circ} \mathrm{C}$ to $950^{\circ} \mathrm{C}$ whereas a sudden increase can be observed in the recovery of metal at $975^{\circ} \mathrm{C}$ which remained constant as the temperature was increased up to $1000^{\circ} \mathrm{C}$. It can be noted that the recovery was quite low at temperatures $900^{\circ} \mathrm{C}, 925^{\circ} \mathrm{C}$ and $950^{\circ} \mathrm{C}$ i.e. $32.55 \%, 42.46 \%$ and $53.78 \%$ respectively but as the temperature was increased to $975^{\circ} \mathrm{C}$ a substantial quantity of metal i.e. $98.52 \%$ was recovered which was observed to be almost the same at $1000^{\circ} \mathrm{C}$. It is therefore inferred that the optimum temperature for the extraction of antimony metal through this process is $975^{\circ} \mathrm{C}$, as further increase in the temperature was found to be ineffective (Figure 2).

\subsubsection{Effect of Reaction Time}

The effect of time on extraction of antimony from stibnite ore was studied and results are given in Table 4. A series of experiments were conducted by varying time for 20, 40, 60 and 80 minutes using sodium chloride, $15 \%$ of the weight of the reaction mixture, as flux, keeping temperature at $975^{\circ} \mathrm{C}$. It is evident from the results that only $52.37 \%$ metal is recovered when the mixture was heated for 20 minutes. The results indicate that the rate of recovery was increased with increase in time duration. However, as the time was increased for 40, 60 and 80 minutes almost similar results were obtained i.e. $98.52 \%-98.76 \%$. Therefore, 
Table 1. X-ray diffraction (XRD) data.

\begin{tabular}{|c|c|c|c|c|}
\hline Pos. ['2Th.] & Height [cts] & FWHM [ $\left.{ }^{\circ} 2 \mathrm{Th}.\right]$ & d-spacing $[\AA]$ & Rel. Int. [\%] \\
\hline 15.8220 & 71.99 & 0.3149 & 5.60134 & 7.90 \\
\hline 17.8330 & 135.33 & 0.1968 & 4.97396 & 14.84 \\
\hline 21.1832 & 377.40 & 0.1968 & 4.19427 & 41.39 \\
\hline 22.5423 & 46.12 & 0.2362 & 3.94437 & 5.06 \\
\hline 25.1727 & 295.47 & 0.2362 & 3.53786 & 32.41 \\
\hline 26.9494 & 911.80 & 0.1574 & 3.30852 & 100.00 \\
\hline 27.8890 & 82.46 & 0.2362 & 3.19915 & 9.04 \\
\hline 28.7984 & 127.64 & 0.1574 & 3.10016 & 14.00 \\
\hline 29.4844 & 91.50 & 0.2362 & 3.02957 & 10.03 \\
\hline 30.3255 & 25.61 & 0.3149 & 2.94744 & 2.81 \\
\hline 32.6441 & 102.32 & 0.4723 & 2.74320 & 11.22 \\
\hline 33.7017 & 38.36 & 0.3149 & 2.65950 & 4.21 \\
\hline 35.7829 & 203.17 & 0.1968 & 2.50944 & 22.28 \\
\hline 36.8882 & 228.08 & 0.1968 & 2.43675 & 25.01 \\
\hline 39.8027 & 59.73 & 0.4723 & 2.26479 & 6.55 \\
\hline 40.6809 & 75.82 & 0.3149 & 2.21790 & 8.32 \\
\hline 42.7179 & 166.66 & 0.2362 & 2.11674 & 18.28 \\
\hline 46.0837 & 33.31 & 0.4723 & 1.96967 & 3.65 \\
\hline 47.0066 & 109.00 & 0.3149 & 1.93313 & 11.95 \\
\hline 48.4745 & 44.65 & 0.2362 & 1.87797 & 4.90 \\
\hline 50.3546 & 121.42 & 0.2755 & 1.81218 & 13.32 \\
\hline 53.2251 & 51.07 & 0.3149 & 1.72101 & 5.60 \\
\hline 54.4307 & 117.42 & 0.3149 & 1.68571 & 12.88 \\
\hline 60.2287 & 70.25 & 0.2362 & 1.53657 & 7.70 \\
\hline 62.9998 & 18.13 & 0.4723 & 1.47549 & 1.99 \\
\hline 64.7473 & 10.67 & 0.9446 & 1.43982 & 1.17 \\
\hline 67.9022 & 468.26 & 0.1181 & 1.38041 & 51.36 \\
\hline 72.2709 & 22.15 & 0.3149 & 1.30735 & 2.43 \\
\hline 81.6899 & 41.37 & 0.7680 & 1.17780 & 4.54 \\
\hline
\end{tabular}

Table 2. Mineralogical data of stibinite ore.

\begin{tabular}{cc}
\hline Constituents & Results (\%) \\
\hline $\mathrm{Sb}_{2} \mathrm{~S}_{3}$ & 66.01 \\
$\mathrm{Sb}_{2} \mathrm{O}_{3}$ & 5.22 \\
$\mathrm{Fe}_{2} \mathrm{O}_{3}$ & 0.53 \\
$\mathrm{Al}_{2} \mathrm{O}_{3}$ & 0.21 \\
$\mathrm{CaO}$ & 0.33 \\
$\mathrm{SiO}_{2}$ & 27.32 \\
$\mathrm{MgO}$ & 0.07 \\
\hline
\end{tabular}




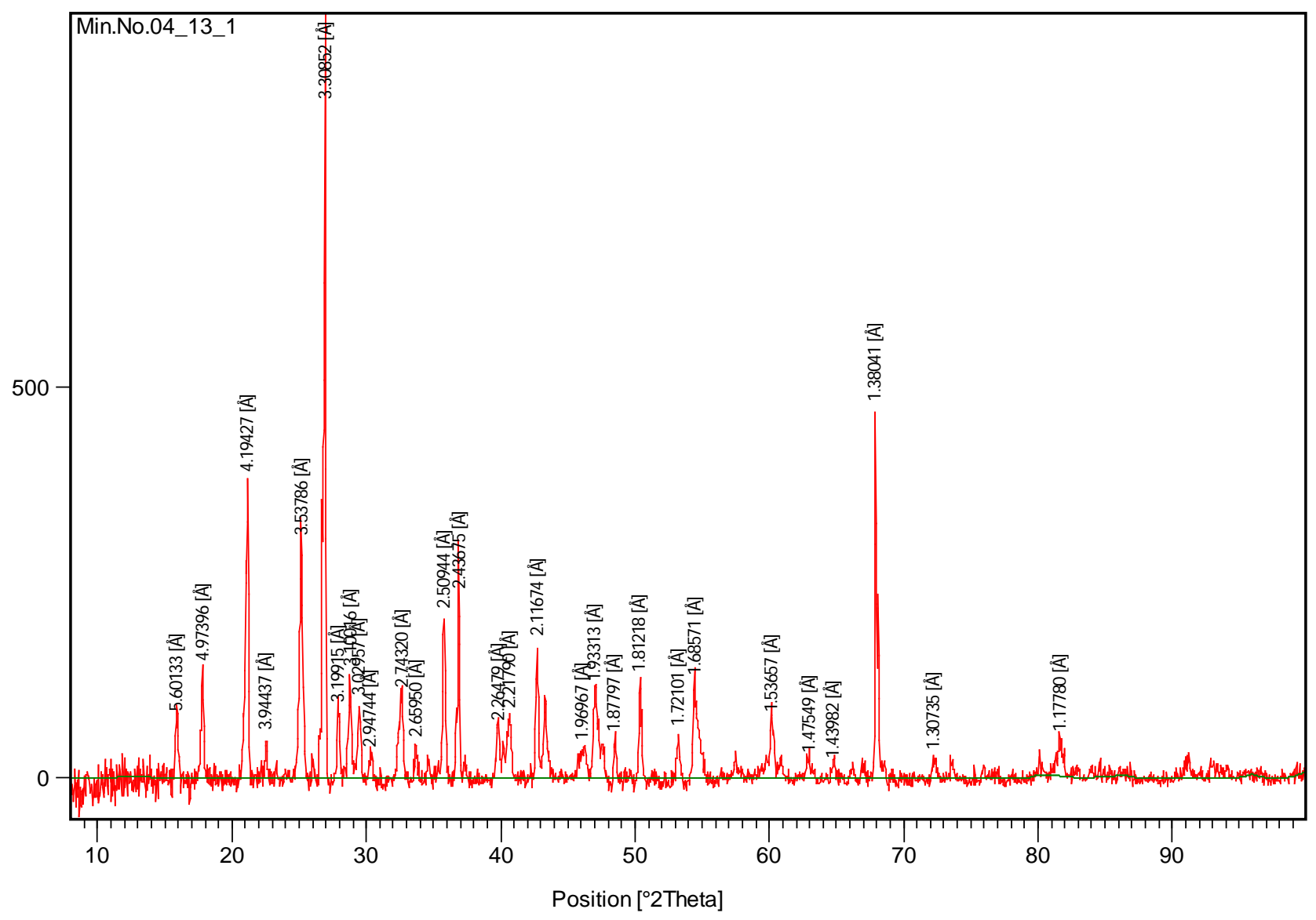

Figure 1. X-ray diffraction (XRD) of Kharan (Balochistan, Pakistan) stibnite.

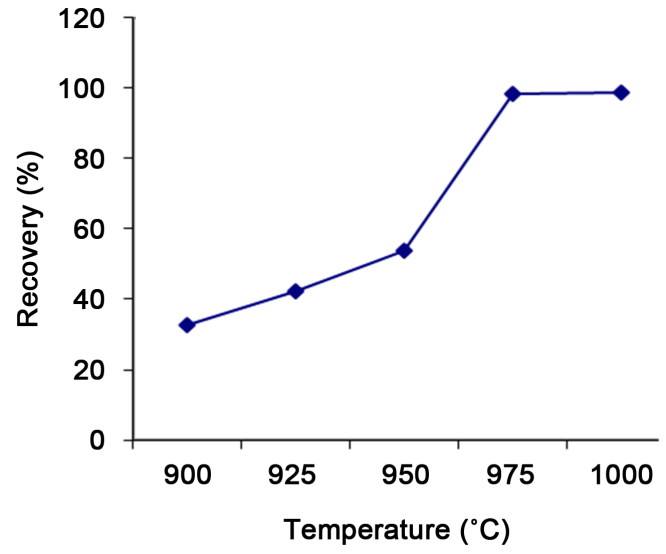

Figure 2. Effect of reaction temperature for recovery yield.

Table 3. Effect of reaction temperature on recovery of antimony.

\begin{tabular}{cc}
\hline Temperature $\left({ }^{\circ} \mathrm{C}\right)$ & Recovery Yield (\%) \\
\hline 900 & 32.55 \\
925 & 42.46 \\
950 & 53.78 \\
975 & 98.52 \\
1000 & 98.80 \\
\hline
\end{tabular}


heating for 40 minutes was found to be the most significant and further increase in reaction time showed no appreciable change in recovery of antimony which also consumes more energy in addition to increased antimony volatilization [14] (Figure 3).

\subsubsection{Effect of Flux Concentration}

Sodium chloride was used as flux in the present study to reduce volatilization of antimony metal and enhance the dissolution of gangue minerals [16]. A number of experiments were carried out at different concentrations of sodium chloride i.e. $5 \%, 10 \%, 15 \%, 20 \%$ and $25 \%$ of the weight of the reaction mixture, keeping all other parameters constant and results are illustrated in Figure 4. The figure shows a regular increase in the recovery of antimony up to $15 \%$ and as the concentration of flux is increased to $20 \%-25 \%$, no considerable change in the recovery is observed. It is therefore noted that 15 weight percent of flux was found to be appropriate at which $98.52 \%$ of the metal was recovered as further addition of flux only affects the consistency of reaction mixture and shows no prominent increase in the recovery yield of metal (Table 5).

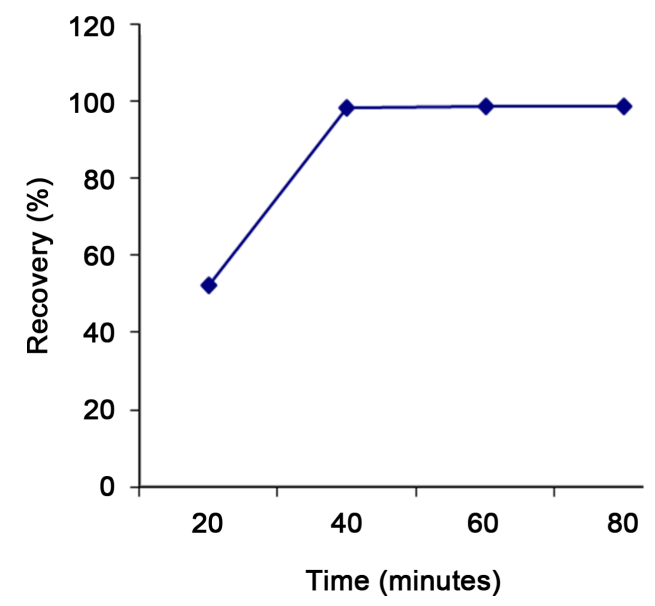

Figure 3. Effect of reaction time vs recovery yield.

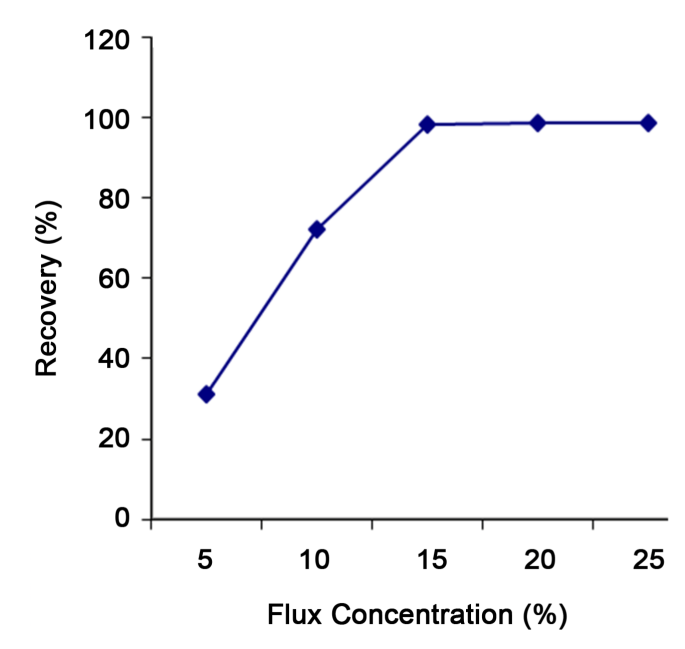

Figure 4. Effect of flux concentration vs recovery yield. 


\subsection{Confirmation Experiment}

A confirmation experiment was carried out for the extraction of antimony metal from stibnite ore at optimum conditions to substantiate the entire procedure. For this purpose 500 gm of the ore and iron scrape were mixed in stoichiometric ratio and the mixture was heated at $975^{\circ} \mathrm{C}$ for 40 minutes in the presence of 15 weight percent of sodium chloride as flux. The metal thus obtained was $99.95 \%$ pure, as confirmed through X-ray fluorescence technique and results are reported in Table 5. The yield calculated on the basis of stibnite present in the ore was $98.52 \%$ which is an evidence of the fact that the remaining $1.48 \%$ of the metal present as sulfide mineral was captured as slag. The study reveals that antimony present as an oxide mineral in the ore is not taking part in the recovery of metal; the reason being the procedure followed for the extraction exclusively exploits the sulphide mineral. However, the metal left in the slag can be recovered by performing a second step but it will certainly involve pretreatment of slag and consumption of extensive energy that will reduce the economics of the process (Figure 5).

\section{Conclusion}

The present study provides a one step process for recovery of antimony metal (Table 6) from its ore containing $66 \%$ sulfide mineral. The process parameters
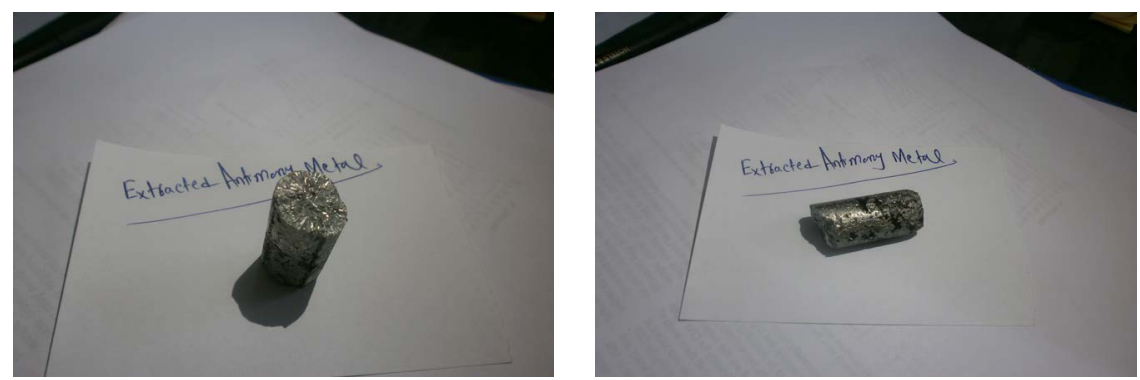

Figure 5. Photograph of extracted antimony metal.

Table 4. Effect of reaction time on recovery of antimony.

\begin{tabular}{cc}
\hline Flux Concentration (\%) & Recovery Yield (\%) \\
\hline 5 & 31.14 \\
10 & 72.18 \\
20 & 98.52 \\
25 & 98.64 \\
\hline
\end{tabular}

Table 5. Effect of flux concentration on recovery of antimony.

\begin{tabular}{cc}
\hline Time (minutes) & Recovery Yield (\%) \\
\hline 20 & 52.37 \\
40 & 98.52 \\
60 & 98.68 \\
80 & 98.76 \\
\hline
\end{tabular}


Table 6. Analysis of recovered antimony metal.

\begin{tabular}{ccccc}
\hline Sr. No. & Symbol & No. of Impulses & Concentration & Unit \\
\hline 47 & $\mathrm{Ag}$ & $477 \mathrm{~F}$ & 0.1144 & $\%$ \\
48 & $\mathrm{Cd}$ & $506 \mathrm{~F}$ & 0.1527 & $\%$ \\
49 & $\mathrm{In}$ & $622 \mathrm{~F}$ & 0.249 & $\%$ \\
50 & $\mathrm{Sn}$ & $444 \mathrm{~F}$ & 0.143 & $\%$ \\
51 & $\mathrm{Sb}$ & $112997 \mathrm{~F}$ & $\sim 94.08$ & $\%$ \\
73 & $\mathrm{Ta}$ & $459 \mathrm{~F}$ & 0.0546 & $\%$ \\
74 & $\mathrm{~W}$ & $1512 \mathrm{~F}$ & 0.2501 & $\%$ \\
77 & $\mathrm{Ir}$ & 0 & $<0.0010$ & $\%$ \\
78 & $\mathrm{Pt}$ & 0 & $<0.020$ & $\%$ \\
79 & $\mathrm{Au}$ & 0 & $<0.020$ & $\%$ \\
82 & $\mathrm{~Pb}$ & $4599 \mathrm{~F}$ & $<0.4138$ & $\%$ \\
\hline
\end{tabular}

for the extraction of metal were optimized on laboratory scale and $975^{\circ} \mathrm{C}$ reaction temperature, 40 minutes reaction time and 15 weight percent of sodium chloride as flux were found to be the optimal conditions. The purity of metal thus obtained was $99.95 \%$ and its recovery calculated on the basis of stibnite present in ore was found to be $98.52 \%$. Since the process involves no up-gradation through froth-flotation and the ore is employed directly for extraction; therefore single step and application of lower temperature results in consumption of less energy and low volatility of antimony metal that makes the process economically feasible and reduces environmental hazards during metal extraction.

\section{References}

[1] Bhatti, M.A., Kazmi, K.R., Nizami, M.S., Anwar, M.A., Saleemi, A.A. and Butt, K. (2009) Mineralogical and Liberation Characteristics of Antimony Ore of Chitral, NWFP, Pakistan. Journal of the Chemical Society of Pakistan, 31, 39-45.

[2] Mineral Profile of Balochistan (2009) Geological Survey of Pakistan. Ministry of Petroleum and Natural Resources. http://www.scribd.com

[3] Riaz, M., Jan, N., Hussain, M.T., Khan, F. and Yamin, A. (2008) Flotation Studies of Low Grade Stibnite Ore form Krinj (Chitral) Area. Journal of the Chemical Society of Pakistan, 30, 584-587.

[4] Lin, H.K. (2004) Extraction of Antimony by a Copper Chloride Extractant. Hydrometallurgy, 73, 283-291. https://doi.org/10.1016/j.hydromet.2003.12.008

[5] Sargar, B.M., Rajmane, M.M. and Anuse, M.A. (2004) Selective Liquid-Liquid Extraction of Antimony (III) from Hydrochloric Acid Media by N-n-Octylaniline in Xylene. Journal of the Serbian Chemical Society, 69, 283-298. https://doi.org/10.2298/JSC0404283S

[6] Madkour, L.H. and Salem, I.A. (1996) Electrolytic Recovery of Antimony from Natural Stibnite Ore. Hydrometallurgy, 43, 265-275. https://doi.org/10.1016/0304-386X(95)00113-U

[7] Mahlangu, T., Gudyanga, F.P. and Simbi, D.J. (2006) Reductive Leaching of Stibnite 
$\left(\mathrm{Sb}_{2} \mathrm{~S}_{3}\right)$ Flotation Concentrate Using Metallic Iron in a Hydrochloric Acid Medium I: Thermodynamics. Hydrometallurgy, 84, 192-203. https://doi.org/10.1016/j.hydromet.2006.05.014

[8] Ubaldini, S., Veglio, F., Fornari, P. and Abbruzzese, C. (2000) Process Flow-Sheet for Gold and Antimony Recovery from Stibnite. Hydrometallurgy, 57, 187-199. https://doi.org/10.1016/S0304-386X(00)00107-9

[9] Smincakova, E. and Komorova, L. (2009) Leaching of Natural Stibnite in $\mathrm{NaOH}$ Solutions. Journal of Minerals, Metals \& Material Society, 6, 32-35. https://doi.org/10.1007/s11837-009-0149-9

[10] Smincakova, E. and Raschman, P. (2012) Kinetics of Leaching of Stibnite by Mixed $\mathrm{Na}_{2} \mathrm{~S}$ and $\mathrm{NaOH}$ Solutions. Hydrometallurgy, 113-114, 60-66. https://doi.org/10.1016/j.hydromet.2011.11.017

[11] Veglio, F. and Ubaldini, S. (2001) Optimisation of Pure Stibnite Leaching Conditions by Response Surface Methodology. European Journal of Mineral Processing and Environmental Protection, 1, 103-112.

[12] Yang, J., Yang, S. and Tang, C. (2010) The Membrane Electrowinning Separation of Antimony from a Stibnite Concentrate. Metallurgical and Materials Transactions $B$, 41, 527-534. https://doi.org/10.1007/s11663-010-9353-9

[13] Godocikova, E., Takacs, L., Balaz, P., Kovac, J., Satka, A. and Briancin, J. (2008) Mechanochemical Reduction of Antimony Sulphide $\mathrm{Sb}_{2} \mathrm{~S}_{3}$ with Magnesium in a Planetary Mill. Reviews on Advanced Materials Science, 18, 212-215.

[14] Yang, J., Tang, C., Chen, Y. and Tang, M. (2011) Separation of Antimony from Stibnite Concentrate through a Low-Temperature Smelting Process to Eliminate $\mathrm{SO}_{2}$ Emission. Metallurgical and Materials Transactions B, 42, 30-36. https://doi.org/10.1007/s11663-010-9453-6

[15] Chen, Y., Huang, C., Tang, M., Yao, W., Tang, C. and Pi, G. (2005) Production of Antimony by Directly Reducing-Matting Smelting of Stibnite Concentrate. The Chinese Journal of Nonferrous Metals, 15, 1311-1317.

[16] Anderson, C.G. (2012) The Metallurgy of Antimony. Chemie der Erde, 72, 3-8. https://doi.org/10.1016/j.chemer.2012.04.001

\section{Submit or recommend next manuscript to SCIRP and we will provide best service for you:}

Accepting pre-submission inquiries through Email, Facebook, LinkedIn, Twitter, etc. A wide selection of journals (inclusive of 9 subjects, more than 200 journals) Providing 24-hour high-quality service User-friendly online submission system Fair and swift peer-review system Efficient typesetting and proofreading procedure Display of the result of downloads and visits, as well as the number of cited articles Maximum dissemination of your research work

Submit your manuscript at: http://papersubmission.scirp.org/

Or contact jmmce@scirp.org 